\title{
Improving Student's Initial Reading Skills Using Flash Card Media
}

\section{Fitri Nurjayani}

Universitas Sebelas Maret Surakarta

fitrinurjayani@yahoo.co.id

\section{Article History}

received 30/4/2021

\begin{abstract}
This study aims to improve initial reading skills in grade II students of SDN 2 Ketitang in the 2020/2021 academic year using flash card media. The research conducted was Classroom Action Research in three cycles, with each cycle consisting of two meetings conducted online through face-to-face using facebook video conference. The stages of each cycle are planning, implementation, observation and reflection. At each meeting, a preliminary reading skill test is carried out through whatsapp voicenotes to determine the development of students' initial reading skills. The criteria for initial reading skills used are the accuracy of reading words or sentences, clarity of pronunciation and intonation, reading speed and voice volume. In the first cycle, the number of students who got the initial reading skill score 75 was $47.06 \%$ or 8 out of 17 students. In the second cycle, the number of students who got the initial reading skill score 75 was $58.82 \%$ or 10 out of 17 students. In the third cycle, the number of students who got the initial reading skill score 75 was $82.35 \%$ or 14 of the 17 students. These results show that flash card media can improve initial reading skills in class II students of SDN 2 Ketitang in the 2020/2021 school year.
\end{abstract}

Keywords: Initial Reading Skills, Flash Card, Grade 2 Elementary School.

\begin{abstract}
Abstrak
Penelitian ini bertujuan untuk meningkatkan keterampilan membaca permulaan pada peserta didik kelas II SDN 2 Ketitang tahun pelajaran 2020/2021 menggunakan media flash card. Penelitian yang dilakukan adalah Penelitian Tindakan Kelas sebanyak tiga siklus, dengan setiap siklusnya terdiri dari dua pertemuan dilakukan secara daring melalui tatap layar menggunakan video conference facebook. Tahapan setiap siklusnya adalah perencanaan, pelaksanaan, observasi dan refleksi. Setiap pertemuan dilakukan test keterampilan membaca permulaan melalui voicenote whatsapp untuk mengetahui perkembangan keterampilan membaca permulaan pada peserta didik. Kriteria keterampilan membaca permulaan yang digunakan adalah ketepatan membaca kata atau kalimat, kejelasan Lafal dan Intonasi, kecepatan membaca dan volume suara. Pada siklus I jumlah peserta didik yang mendapatkan nilai keterampilan membaca permulaan $\geq 75$ adalah $47,06 \%$ atau 8 dari 17 peserta didik. Pada siklus II jumlah peserta didik yang mendapatkan nilai keterampilan membaca permulaan $\geq 75$ sebanyak 58,82\% atau 10 dari 17 peserta didik. Pada siklus III jumlah peserta didik yang mendapatkan nilai keterampilan membaca permulaan $\geq 75$ sebanyak $82,35 \%$ atau 14 dari 17 peserta didik. Hasil ini menunjukan bahwa media flash card dapat meningkatkan keterampilan membaca permulaan pada peserta didik kelas II SDN 2 Ketitang tahun pelajaran 2020/2021.
\end{abstract}

Kata kunci: Keterampilan membaca permulaan, Flash Card, Kelas 2 Sekolah Dasar. 


\section{PENDAHULUAN}

Salah satu aspek yang dikembangkan sejak usia dini ialah bahasa. Kemampuan bahasa sangat penting bagi anak, karena bahasa merupakan alat yang dipakai oleh anak untuk menyampaikan keinginan, pikiran, harapan, dan lain-lain untuk kepentingan pribadinya. Bahasa merupakan media komunikasi, karena memberikan keterampilan kepada anak untuk dapat berkomunikasi dan mengekspresikan dirinya agar anak dapat menjadi bagian dari kelompok sosialnya. Perkembangan bahasa anak secara keseluruhan mencakup berbagai aspek diantaranya: kemampuan mendengar, berbicara, menulis dan membaca. Salah satu bagian aspek dari perkembangan bahasa ialah membaca. Membaca merupakan proses yang kompleks, artinya banyak segi dan banyak faktor yang mempengaruhinya. Kemampuan membaca merupakan kemampuan yang sangat mendasar karena kemampuan membaca menjadi dasar untuk mengembangkan kemampuan yang lain.

Keterampilan membaca yang diperoleh pada membaca permulaan akan sangat berpengaruh terhadap keterampilan membaca lanjut, sebagai kemampuan yang mendasari kemampuan berikutnya maka keterampilan membaca permulaan benarbenar memerlukan perhatian guru, membaca permulaan di kelas II merupakan pondasi bagi pengajaran selanjutnya. Sebagai pondasi haruslah kuat dan kokoh, oleh karena itu harus dilayani dan dilaksanakan secara berdaya guna dan sungguh-sungguh.

Membaca permulaan yang di laksanakan di kelas II adalah agar peserta didik dapat membaca kata-kata dan kalimat sederhana dengan lancar dan tepat. Menurut Suriani (2016) membaca merupakan suatu aktivitas yang dilakukan untuk mendapatkan sebuah informasi, memperoleh ilmu dan pengetahuan serta pengalaman pengalaman baru. Tujuan membaca permulaan diantaranya adalah: pembinaan dasardasar mekanisme membaca, mampu memahami dan menyuarakan kalimat sederhana yang diucapkan dengan intonasi yang wajar, dan membaca kalimat sederhana dengan lancar dan tepat.

Pembelajaran membaca permulaan yang dilakukan saat ini menggunakan metode drill dan media papan tulis. Guru sudah memberikan contoh cara membaca kata dan kalimat tetapi keterampilan membaca permulaan peserta didik masih rendah karena guru belum menggunakan media yang menarik perhatian peserta didik. Rendahnya keterampilan membaca ini diperoleh dari hasil tes membaca nyaring ternyata dari seluruh peserta didik ada setengah dari jumlah peserta didik kelas II masih belum lancar membaca. Seharusnya peserta didik dapat berperan langsung dalam situasi belajar, guru sebagai perancang, motivator, pengamat dan pengembang di pihak lain peserta didik didorong untuk memberikan respon individual serta secara aktif melaksanakan berbagai kegiatan sehingga dapat memberikan pengalaman dan penghayatan secara langsung.

Pembelajaran membaca seharusnya dapat memberikan pengalaman pada peserta didik yaitu dengan melibatkan langsung peserta didik pada proses pembelajaran seperti permainan bahasa dan juga pemakaian media yang dapat melibatkan peserta didik. Untuk itu guru perlu menyediakan pembelajaran yang menarik yang dapat menimbulkan daya tarik bagi peserta didik untuk giat secara aktif dan kreatif. Selaras dengan pendapat Ariastuti (2017) bahwa media pembelajaran memiliki fungsi utama untuk meningkatkan motivasi peserta didik dan mencegah kebosanan peserta didik dalam belajar. Media dapat menjadi alat bantu untuk meningkatkan motivasi peserta didik jika digunakan dengan tepat namun juga sebaliknya jika guru tidak memilih media yang tepat sesuai materi pembelajaran.

Tindakan yang akan dilaksanakan pada keterampilan membaca peserta didik yang masih rendah dengan menerapkan pembelajaran yang dapat mengakomodasi setiap peserta didik dengan memperhatikan perkembangan dan kesulitan membaca peserta didik. Penggunaan media sederhana yang mudah dioperasikan dan memberikan efek membangkitkan motivasi peserta didik dirasa perlu. Media memiliki 
peran penting dalam pembelajaran. Tidak hanya sebagai penyampai pesan atau alat penyampai materi semata tapi juga bisa menjadi materi pembelajaran itu sendiri. Media juga digunakan untuk menarik minat peserta didik agar termotivasi dengan pembelajaran yang disampaikan oleh guru.

Guru dapat menggunakan satu atau beberapa media sesuai dengan kebutuhan dan kesesuaian materi pembelajaran yang akan disampaikan. Dari berbagai macam dan fungsi media, salah satu bentuknya adalah media flash card. Angreany (2017) berpendapat bahwa flash card merupakan salah satu media pembelajaran yang berbentuk grafis berupa kartu kecil bergambar, biasanya terbuat dengan menggunakan foto, simbol, atau gambar yang ditempelkan pada sisi depan dan pada sisi belakang terdapat keterangan berupa kata atau kalimat dari gambar flash card tersebut. Flash card sesuai untuk digunakan dalam pembelajaran membaca permulaan karena memiliki beberapa kelebihan dikemukakan oleh Indriana dalam Maryanto (2017) kelebihan yang pertama adalah mudah dibawa kemana-mana karena ukurannya yang tidak besar dan ringan. Kedua adalah praktis dalam membuat dan menggunakanya, sehingga lebih efektif dan efisien. Ketiga, media flash card mudah diingat karena kartu ini bergambar dan sangat menarik perhatian, memuat huruf atau angka yang simpel, sehingga merangsang otak untuk lebih lama mengingat pesan yang ada.

\section{METODE}

Penelitian ini adalah penelitian tindakan kelas yang menerapkan media flash card untuk menigkatkan keterampilan membaca permulaan peserta didik. Warso (2017) mengemukakan prosedur pelaksanaan penilitian tindakan kelas, yaitu: penetapan fokus permasalahan, perencanaan tindakan, pelaksanaan tindakan, pengamatan/observasi dan pengumpulan data, terakhir adalah refleksi. Analisis penelitian ini adalah analisis deskriptif kuantitafif kualitatif dimana dalam penelitian ini selain penyajian hasil berupa data maupun angka peneliti juga menentukan bagaimana cara pengolahan hasil penelitian yakni dengan membuat analisisnya pada menerapkan media flash card untuk meningkatkan keterampilan membaca permulaan peserta didik. Penelitian ini dilaksanakan pada peserta didik kelas II SDN 2 Ketitang Tahun Pelajaran 2020/2021 selama tiga siklus secara daring menggunakan aplikasi video conference facebook dengan dua pertemuan pada setiap siklusnya. Siklus I dilaksanakan pada tanggal 16 dan 23 Februari 2021. Siklus II dilaksanakan pada tanggal 8 dan 17 Maret 2021. Siklus III dilaksanakan pada tanggal 5 dan 12 April 2020. Teknik pengumpulan data yang dilakukan dengan test keterampilan membaca permulaan dengan empat kriteria penilaian yaitu ketepatan membaca kata atau kalimat, kejelasan Lafal dan Intonasi, kecepatan membaca dan volume suara dengan nilai indikator kinerja $\geq 75$. Data didapat dari test keterampilan membaca permulaan peserta didik melalui rekaman suara yang dikirim peserta didik dengan voicenote whatsapp sesuai dengan lembar kerja peserta didik.

\section{HASIL DAN PEMBAHASAN}

Data yang dikumpulkan adalah data partisipasi belajar peserta didik melalui lembar pengamatan penilaian unjuk kerja membaca nyaring dan data prestasi belajar peserta didik melalui soal evaluasi pada setiap pertemuan. Setelah dilaksanakan pembelajaran pada siklus I selanjutnya diadakan tes kemampuan membaca dengan mengirim suara voicenote whatsapp. Sebanyak 8 peserta didik atau 47, 06\% mendapatkan nilai $\geq 75$. Hal ini menunjukkan bahwa terdapat peningkatan 3 peserta didik dari 5 peserta didik sebelum tindakan menjadi 8 peserta didik yang keterampilan membaca permulaannya meningkat pada siklus I. Adapun hasil tes kemampuan membaca permulaan pada siklus I disajikan dalam tabel berikut: 
Volume 9 Nomor 1 Tahun 2021

Tabel 1. Nilai Keterampilan Membaca Permulaan Siklus I

\begin{tabular}{ccc}
\hline Interval Nilai & Frekuensi & Persentase \\
\hline $60-65$ & 2 & $11,77 \%$ \\
$66-71$ & 4 & $23,53 \%$ \\
$72-77$ & 4 & $23,53 \%$ \\
$78-83$ & 6 & $35,29 \%$ \\
$84-89$ & 1 & $5,88 \%$ \\
Jumlah & 17 & $100 \%$ \\
\hline
\end{tabular}

Berdasarkan tabel di atas menunjukkan bahwa setelah tindakan siklus I jumlah peserta didik yang memperoleh nilai dibawah 75 sebanyak 9 peserta didik atau $52,94 \%$. Jumlah peserta didik yang belum mencapai nilai sesuai indikator kinerja mengalami penurunan dari 12 peserta didik sebelum tindakan menjadi 9 peserta didik pada siklus I dari 17 peserta didik kelas II.

Secara garis besar pembelajaran daring dapat berlangsung baik namun belum maksimal. Sebanyak 12 peserta didik dapat mengikuti daring sedangkan 5 peserta didik belum dapat bergabung video conference facebook karena berbagai kendala dan hanya aktif melalui Whatapps Group. Peserta didik yang mengikuti video conference facebook aktif dan antusias dalam pembelajaran. Media flash card yang digunakan dalam pembelajaran daring dapat membantu peserta didik mengidentifikasi dan memahami tentang materi melalui membaca nyaring flash card yang ditampilkan melalui power point sehingga secara langsung berdampak pada keterampilan membaca permulaan peserta didik. Pada Siklus I didapatkan hasil yang belum maksimal dan perlu diadakan perbaikan dengan melanjutkan pada Siklus II. Berikut hasil tes kemampuan membaca permulaan pada siklus I disajikan dalam tabel berikut:

Tabel 2. Nilai Keterampilan Membaca Permulaan Siklus II

\begin{tabular}{ccc}
\hline Interval Nilai & Frekuensi & Persentase \\
\hline $65-68$ & 5 & $29,41 \%$ \\
$69-72$ & 1 & $5,88 \%$ \\
$73-76$ & 2 & $11,77 \%$ \\
$77-80$ & 5 & $29,41 \%$ \\
$81-84$ & 4 & $23,53 \%$ \\
Jumlah & 17 & $100 \%$ \\
\hline
\end{tabular}

Berdasarkan data tabel di atas, sebanyak 10 peserta didik atau 58,82\% mendapatkan nilai $\geq 75$. Hal ini menunjukkan bahwa terdapat peningkatan 2 peserta didik dari 8 peserta didik pada siklus I menjadi 10 peserta didik yang keterampilan membaca permulaannya meningkat pada siklus II. Secara garis besar pembelajaran daring cukup baik dan lancar semua peserta didik dapat mengikuti pembelajaran yang dilakukan. Peserta didik yang mengikuti video conference facebook aktif dan antusias dalam pembelajaran. Media flash card yang digunakan dalam pembelajaran daring dapat membantu peserta didik mengidentifikasi dan memahami tentang materi melalui membaca nyaring flash card yang ditampilkan melalui power point sehingga secara langsung berdampak pada keterampilan membaca permulaan peserta didik. Pada Siklus II indikator kinerja masih belum tercapai sehingga dilanjutkan ke siklus III. Adapun hasil tes kemampuan membaca permulaan pada siklus III disajikan dalam tabel berikut: 
Volume 9 Nomor 1 Tahun 2021

Tabel 3. Nilai Keterampilan Membaca Permulaan Siklus III

\begin{tabular}{ccc}
\hline Interval Nilai & Frekuensi & Persentase \\
\hline $68-71$ & 3 & $17,65 \%$ \\
$72-75$ & 2 & $11,77 \%$ \\
$76-79$ & 4 & $23,52 \%$ \\
$80-83$ & 5 & $29,41 \%$ \\
$84-87$ & 3 & $17,65 \%$ \\
Jumlah & 17 & $100 \%$ \\
\hline
\end{tabular}

Berdasarkan data pada tabel 4.7 di atas, sebanyak 14 peserta didik atau $82,35 \%$ mendapatkan nilai $\geq 75$. Hal ini menunjukkan bahwa terdapat peningkatan 4 peserta didik dari 10 peserta didik pada siklus II menjadi 14 peserta didik yang keterampilan membaca permulaannya meningkat pada siklus III. Media flash card memiliki dampak positif terhadap kegiatan pembelajaran daring yang dilakukan melalui video conference facebook dan menigkatkan keterampilan membaca permulaan peserta didik kelas II SDN 2 Ketitang. Hal ini terbukti bahwa adanya peningkatan jumlah peserta didik yang mencapai indikator kinerja untuk menilai keterampilan membaca permulaan. Hasil penelitian ini juga sesuai dengan penelitian sebelumnya dari Wiji Lestariningsih yang berjudul upaya meningkatkan kemampuan membaca awal melalui permainan kartu huruf.

\section{SIMPULAN}

Berdasarkan hasil penelitian tindakan kelas yang telah dilaksanakan dalam tiga siklus dengan menggunakan media flash card dalam pembelajaran pada peserta didik kelas II SDN 2 Ketitang dapat disimpulkan keadaan sebelum dilakukan tindakan, siklus I, siklus II, dan siklus III mengalami peningkatan. Penerapan media flash card ini masih terdapat beberapa kendala yang ditemui dalam pembelajaran antara lain waktu, membutuhkan bimbingan dari guru supaya peserta didik fokus pada kata atau kalimat pada flash card tidak hanya pada gambar yang ada pada flash card, kondisi kelas daring sangat berbeda dengan kondisi tatap muka karena perlu koordinasi dengan peserta didik dan perangkat serta jaringan yang baik, dan ada peserta didik yang mengalami kendala untuk mengikuti pembelajaran daring. Namun, sebisa mungkin hambatan - hambatan tersebut dicari solusi dan diatasi dengan berbagai cara sehingga pembelajaran daring dapat berlangsung dengan baik.

\section{DAFTAR PUSTAKA}

Angreany, Femmy. 2017. Keefektifan Media Pembelajaran Flashcard dalam Keterampilan Menulis Karangan Sederhana Bahasa Jerman Peserta didik Kelas XI IPA SMA Negeri 9 Makassar. Eralingua: Jurnal Pendidikan Bahasa Asing dan Sastra Volume 1 No.2 Agustus 2017 halaman 138-146. Diperoleh dari: https://ojs.unm.ac.id/eralingua/article/view/4410/2549

Ariastuti, Anik. 2017. Peningkatan Minat Belajar Bahasa Inggris Peserta didik melalui Media Audio Visual. Jurnal Pendidikan Profesi Vol. 5 No. 2; 283-298. CV. Putra Sukses.

Lestariningsih, Wiji. 2017. Upaya Meningkatkan Kemampuan Membaca Awal melalui Permainan Kartu Huruf. Jurnal Pendidikan Profesi Vol. 7 No. 1 bulan Januari 2019; 113-123. CV. Putra Sukses.

Maryanto, Rahel Ika Primadini. 2017. Penggunaan Media Flashcard untuk Meningkatkan Pengenalan Bentuk Huruf Peserta didik Kelas II pada Mata Pelajaran Bahasa Indonesia di Sekolah ABC Manado. Diperoleh dari Pedagogia: Jurnal IImu Pendidikan: https://ejournal.upi.edu/index.php/pedagogia/article/download/12073/pdf 
Volume 9 Nomor 1 Tahun 2021

Suriani. 2016. Peningkatan Kemampuan Membaca Permulaan Peserta didik Kelas 1 SDN Ginunggung Melalui Media Kartu Huruf Kec. Galang. Jurnal Kreatif Tadulako Online Vol. 4 No. 10; 62-77 diunduh dari: https://media.neliti.com/media/publications/119314-ID-peningkatan-kemampuanmembaca-permulaan.pdf

Warso, Agus Wasisto Dwi Doso. 2017. Penelitian Tindakan Kelas. Yogyakarta: Graha Cendikia. 